\title{
1995 John Howland Award Presentation to Floyd W. Denny, Jr.
}

\author{
JUDSON J. VAN WYK \\ Department of Pediatrics, University of North Carolina School of Medicine, Chapel Hill, \\ North Carolina 27599
}

For the past 43 years, the American Pediatric Society has used the John Howland Award to recognize those pediatric giants who have advanced the objectives of our society. This year's honoree, Floyd W. Denny, has made monumental contributions to each of our society's objectives, among which are: the "advancement of the study of children and their diseases, ... prevention of illness and the promotion of health in childhood, ... and the promotion of pediatric education and research. ..."

\section{THUMBNAIL CURRICULUM VITAE}

Floyd was born and raised in Hartsville, South Carolina. In high school he was fleet of foot as well as fleet of mind, and won varsity letters in basketball, football, and tennis. An early portrait of the future pitcher of a pediatric faculty softball team is shown in Figure 1. In later years his faculty would look to him to spare them from utter humiliation at the hands of their house officers!

After high school, Floyd was awarded a scholarship to Wofford College where his premedical studies were greatly foreshortened by Pearl Harbor, and in 1943 he entered Vanderbilt Medical School under the Army ASTP program. Denny's interest in infectious disease began with an undergraduate course in bacteriology at Wofford College and was cemented in medical school during a pathology externship under Earnest Goodpasture. Denny was particularly influenced by John Buddingh, who was a pioneer in studying the viral etiology of infantile diarrhea.

Floyd was elected to Alpha Omega Alpha in his junior year, and in his senior year was awarded the prestigious Founder's Medal, which each year was awarded the to the student graduating at the top of the senior class.

Dr. Amos Christie was suitably impressed with this young man and recruited him as a pediatric intern at Vanderbilt. The highlight of Denny's residency was his rotation through the Sydenham Infectious Disease Hospital in Baltimore, where he was tutored by Horace Hodes, one of the master clinicians and teachers of 20th century pediatrics and a future Howland Awardee.

Perhaps an even more important highlight of Floyd's residency was his marriage to Barbara Horsefield (Fig. 2). Barbara has been Floyd's pillar of strength for nearly half a century. She is the mother of three very successful children and has

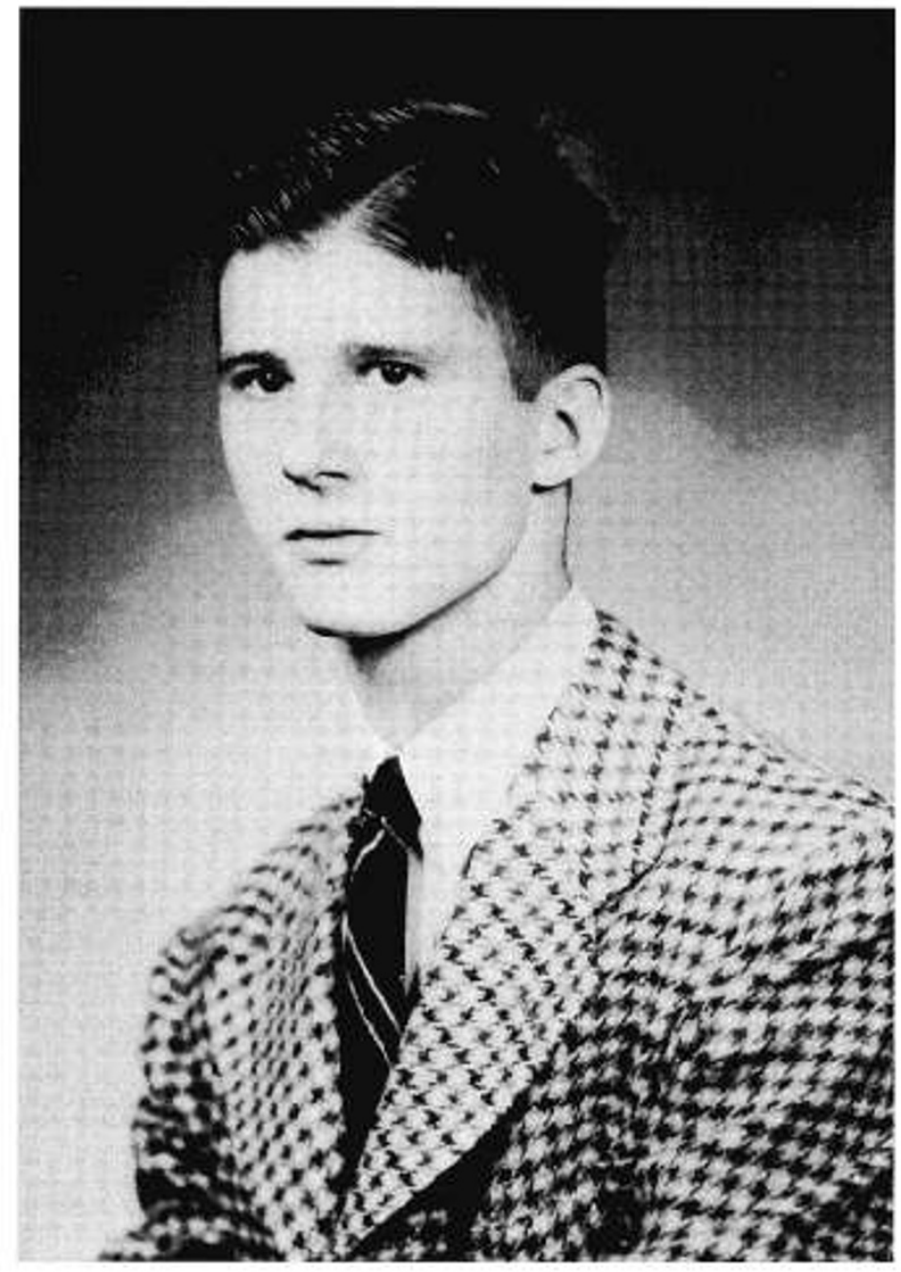

Figure 1. Portrait of the Awardee as a young man.

used her training in clinical social work to establish a successful independent counseling practice.

After only 27 months of pediatric training, Floyd was ordered to active service in the U.S. Army. Although the Army is not noted for its discernment in making personnel decisions, it hit a home run in finding an assignment for Floyd Denny. After Floyd expressed no interest in an assignment to the Far East, the Colonel said, "It says on this here piece of paper that you would like to do research in the army. How would you like to go to Western Reserve University and study rheumatic fever?" Floyd replied, "I don't know where Western Reserve is, but I'd sure like to go there!" 


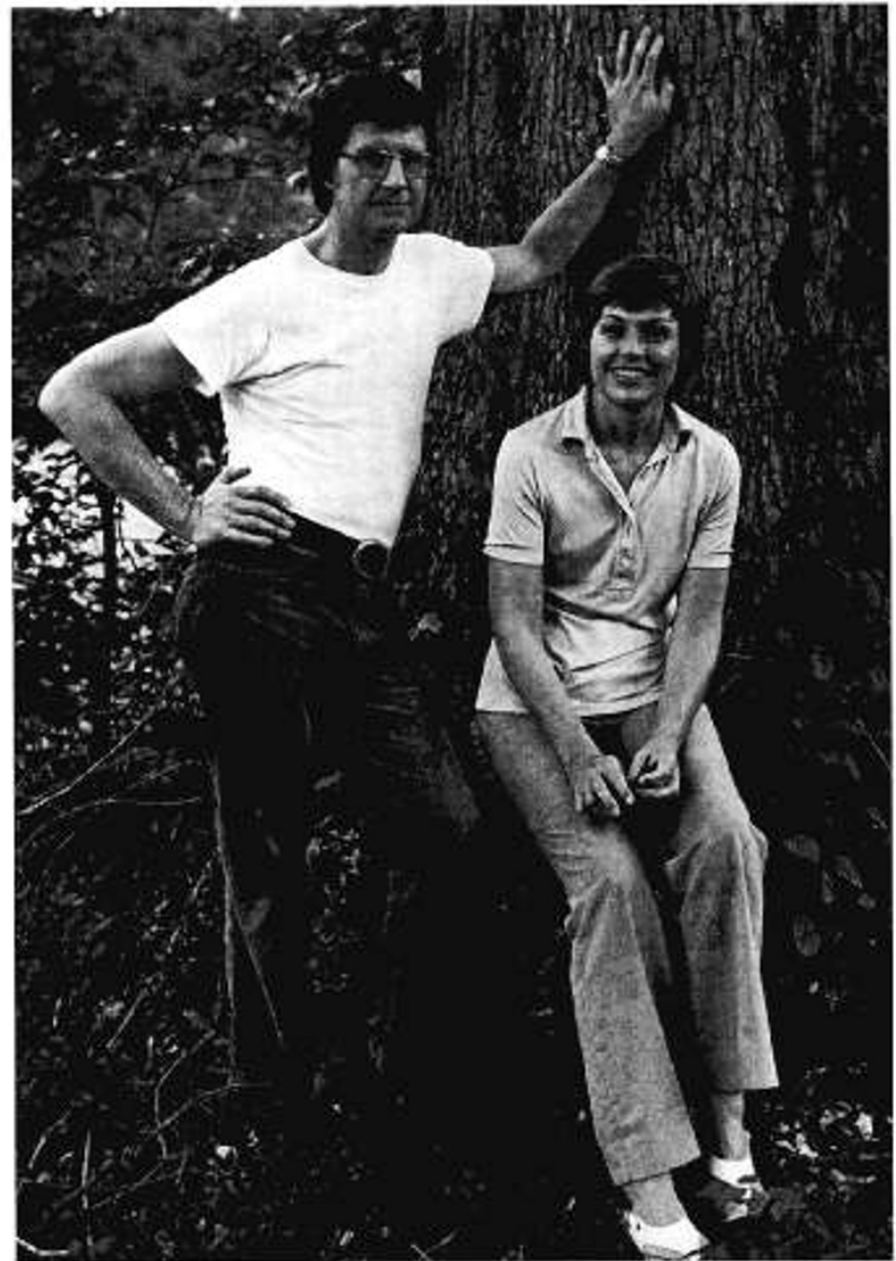

Figure 2. Floyd and Barbara Denny where they love to be: On their farm.

However, when Denny arrived at Western Reserve there was no record of any need for a person to study rheumatic fever, so they assigned him to work with an investigator named Charles Rammelkamp who was planning a study of the common cold in Canada. Finally, things got sorted out and plans were made to study rheumatic fever in a group of military recruits at the Francis E. Warren Air Force Base in Wyoming. Rammelkamp had the idea that rheumatic fever could be prevented if pharyngeal group A streptococcal infections were adequately treated with penicillin.

Although Rammelkamp was father of the project, Denny and Lewis Wannamaker were the principal on-site investigators (Fig. 3). For 2 of his 3 years in the army Denny was the in charge of the Wyoming operations and was first author of his now famous first paper: Denny, FW, Wannamaker, LW, Brink, WR, Rammelkamp, CH, and Custer, EA, "Prevention of Rheumatic Fever: Treatment of the Preceding Streptococcic Infection," Journal of the American Medical Association (1950), 143: 151-153. This landmark communication was the first report of successful rheumatic fever prevention by effective treatment of streptococcal infections and was the basis for the 1954 Lasker Award to members of the streptococcus laboratory.

After Denny's sensational contributions in the Army, Rammelkamp arranged for him to spend several years at the

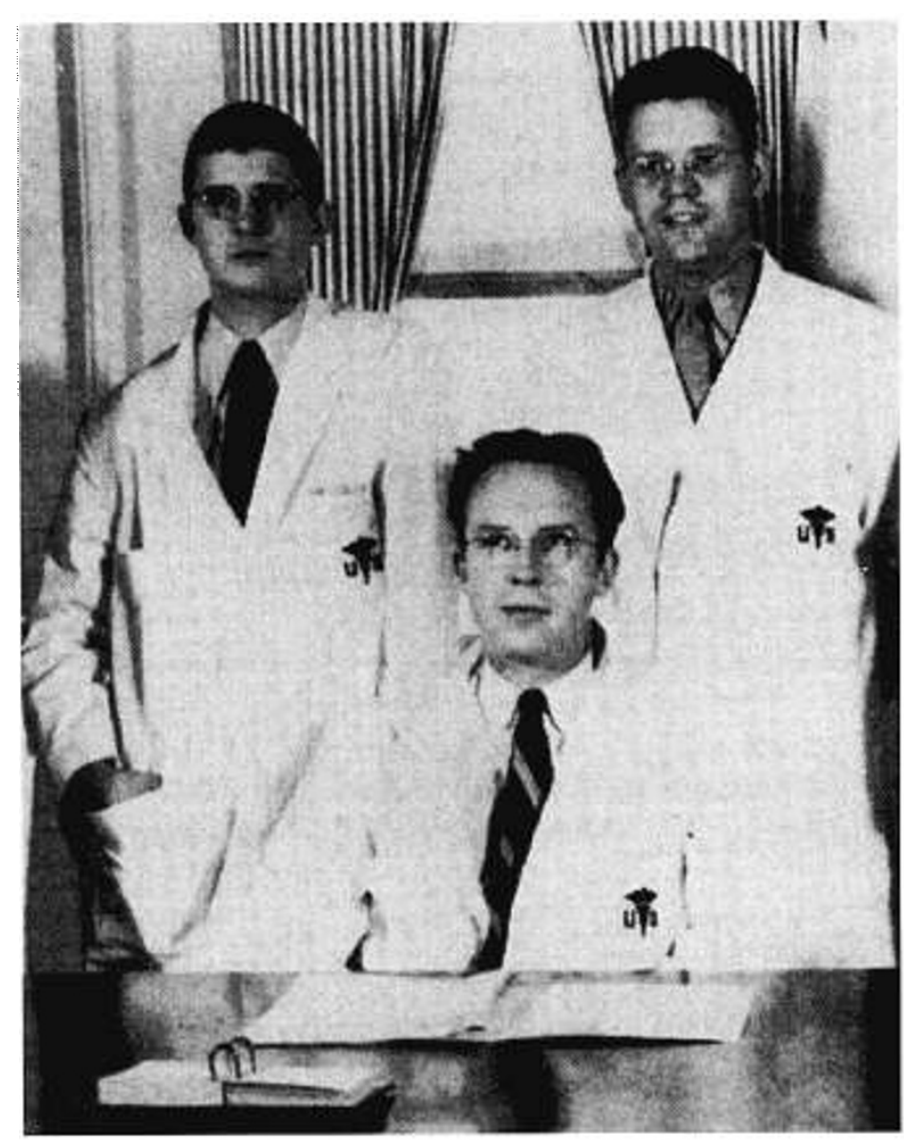

Figure 3. Key members of the Streptococcal Disease Laboratory at Warren Air Force Base in Wyoming, early in 1950. Floyd W. Denny, Charles H. Rammelkamp, Jr., and Lewis W. Wannamaker.

University of Minnesota doing basic research on the Streptococcus with Lewis Thomas. Irvine McQuarrie helped lure Floyd to Minnesota by promising him that the American Board of Pediatrics would close its eyes to the fact that Denny had received only 2 years of formal pediatric training.

After a short stint back at Vanderbilt with Amos Christie, Floyd returned to Western Reserve in the Department of Preventive Medicine under John Dingle. Although the next 5 years at Western Reserve had a profound effect in maturing Denny as a scientist, his secret ambition was to chair a major department of pediatrics and implement his ideas of what a modern department of pediatrics could be. Thus, in 1960, at the age of 37 years, Floyd W. Denny happily accepted the invitation of the University of North Carolina to become its second chairman of pediatrics, succeeding Edward C. Curnen, Jr., who had accepted the chair at Columbia University's Babies and Children's Hospital.

\section{FLOYD DENNY'S CONTRIBUTIONS AS AN INVESTIGATOR}

Denny's scientific tools have been those of the epidemiologist and clinician, and the questions he has addressed have been in the mainstream of pediatrics. Now numbering over 130 reports, Floyd's publications have been focused in three areas. First, we must point to Floyd's pioneering work on streptococcal infections and their consequences. His interest in the epi- 
demiology, pathogenesis, and prevention of rheumatic fever has placed him at the forefront of this area. His studies, for example, of the time required for various antibiotics to rid the pharynx of streptococci have provided a scientific basis for the rational treatment of streptococcal pharyngitis. Prevention of rheumatic fever has saved the lives of countless children and adults, and has spared millions the debilitating effects of acquired heart disease.

Floyd's second area of research defined the role of Mycoplasma pneumoniae in respiratory infections. His studies, carried out in collaboration with his long-time colleague, Wallace Clyde, identified $M$. pneumoniae as the most frequent cause of pneumonia in older children and young adults.

Floyd's third major area of research has been the epidemiology of respiratory infections in children. Several decades ago, Denny and his colleagues inaugurated long-term surveillance studies of respiratory infections in a day care center and in a private pediatric practice. These studies have been continuously funded by the National Institutes of Health (NIH) since 1976. In the study shown in Figure 4, for example, each child with a lower respiratory infection seen in a private pediatric practice was cultured for a wide variety of arcane organisms. Data are plotted for each month for a year. Such data form the basis for much of our current understanding of the seasonal variation in prevalence of the various respiratory syndromes caused by the most common microbial agents and the factors determining susceptibility to these agents.

\section{FLOYD DENNY AS A LEADER}

Under the leadership of Floyd Denny, the Department of Pediatrics at the University of North Carolina grew from 6 faculty and 12 housestaff to a Department with 40 full-time faculty in Chapel Hill and 10 Area Health Education Center faculty, 28 Pediatric housestaff, 16 Medicine/Pediatric housestaff, and a score of postdoctoral fellows. At the end of his chairmanship, the total extramural research support for the Department was approximately $\$ 2,500,000$, funded, in large part, by the NIH.

He played an important role in fashioning the North Carolina Area Health Education Center network that links the medical schools with local communities. He also had the vision to promote strong pediatric programs in Charlotte, Greensboro, and Raleigh that now serve as community-based training sites for students and housestaff.

In the face of enormous pressures to increase clinical income, Floyd's emphasis was steadfastly placed on maintaining the highest standards of scholarship and providing exemplary teaching and patient care. Serving as acting chair of the department while Floyd was abroad on sabbatical, I found that the morale of the pediatric faculty bordered on euphoria. This was particularly remarkable because our salaries were only marginally competitive. I believe that this esprit d'corps reflected the great respect that his faculty had for the chief's priorities and his integrity. Denny chose his faculty carefully and then supported them in reaching their goals without pressure or interference.

After stepping down as Chairman of Pediatrics, Floyd took on the role of Director of the University of North Carolina Medical
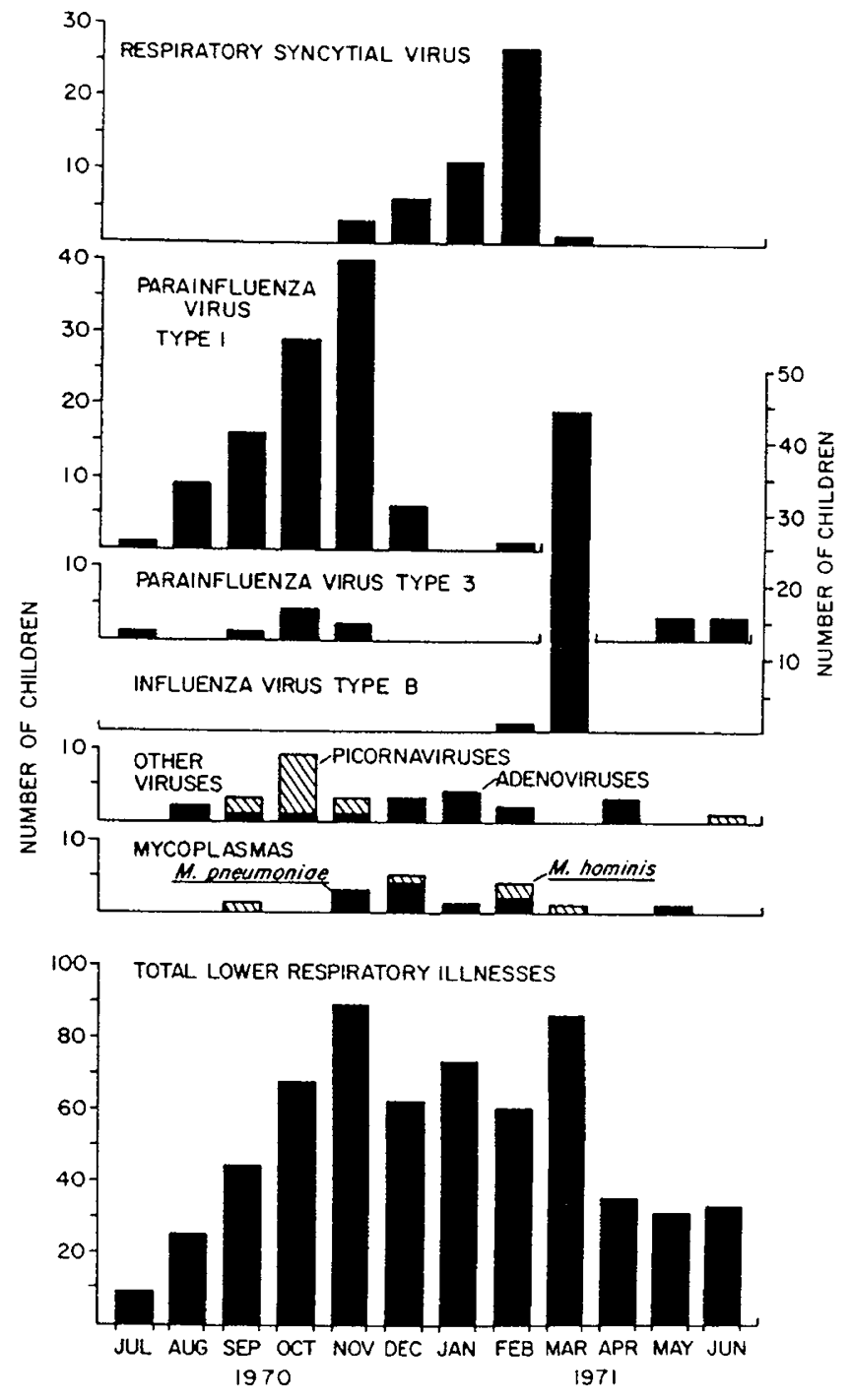

Figure 4. Number of agents isolated by month from children with lower respiratory tract illnesses seen in office practice, 1970-1971. This study illustrated the propensity of some agents to cause discreet outbreaks at a time when other agents were present in only small numbers. Reprinted with permission from Journal of Pediatrics 108: 635-646, 1986.

School Program on Health Promotion and Disease Prevention. This was a logical progression for a man whose academic career began in a Department of Preventive Medicine. Within the Department of Pediatrics, he has remained a consultant in the Division of Infectious Diseases, a beloved teacher, and an advocate for child health in its broadest sense.

For many years Floyd has been an articulate spokesman for pediatric issues in national and international forums. He served with distinction as President of both the Society for Pediatric Research and the American Pediatric Society. He was elected to the American Society for Clinical Investigation, the Association of American Physicians, and to the presidency of the Infectious Diseases Society of America. Floyd also has been a leader in formulating research policy, serving as an advisor to the NIH and the Armed Forces Epidemiological Board, and as a member of the Institute of Medicine of the National Academy of Sciences. 
Every constituency with which Floyd has been associated has bestowed on him its highest awards. Constraints of space permit only a sampling of his more notable recognitions:

1. In addition to Phi Beta Kappa and Alpha Omega Alpha, Floyd received an Honorary Doctor of Science degree from Wofford College, and a Distinguished Alumnus Award from Vanderbilt University School of Medicine.

2. Floyd was honored with The Outstanding Civilian Service Award by the Surgeon General of the Army, The Distinguished Physician Award of the Pediatric Infectious Disease Society, and the James D. Bruce Memorial Award of the American College of Physicians for Distinguished Contributions in Preventive Medicine.

3. The Governor of North Carolina bestowed on Floyd The North Carolina Medal in Science, its highest such award, and in 1988 The Board of Governors of the 16 campus University of North Carolina system awarded him the O. Max Gardner Award, which recognizes that faculty member who was judged to have made the greatest contribution to the welfare of the human race.

\section{FLOYD DENNY AS A TEACHER}

During his 21-year tenure as Chairman of the UNC Department of Pediatrics, Floyd has influenced the development of more than 300 pediatric residents and fellows. Many of these trainees now occupy academic positions in Departments of Pediatrics across the country. When he stepped down as chairman, his trainees commissioned a portrait (Fig. 5), and established the Floyd Denny Pediatric Society to provide an important vehicle for postgraduate education. Floyd Denny's trainees have documented the impact of his teaching efforts more eloquently than anything I can say:

From a Professor and Chairman of a major Department of Pediatrics: "It is clear to me that he has had the most influence on my career of any of my teachers. When I came to the program I had no intention of becoming an academician; when I left I could do nothing else."

From a former resident who is also following an academic career: "The most striking feature about Dr. Denny is his integrity. He is rigid in believing that kindness and consideration are mandatory in caring for ill children and their parents; and that the most important thing that the pediatrician-intraining must learn is how to keep on learning.

From the Director of a Public Health Unit: "One tremendous attribute of Dr. Denny's is his humility. If he doesn't know something he will say so. As we were leaving one of our morning resident rounds, one of our more senior residents said in extremely slow Southern drawl, "For the head of the Department of Pediatrics he knows virtually nothing."

From a former resident in a group practice: "Dr. Denny's contributions to the medical education of so many of us is immeasurable. In 1978, the three of us dedicated our practice to him and in the waiting room a plaque reads:

"Floyd W. Denny, M.D., Professor and Chairman of the Department of Pediatrics at the University of North

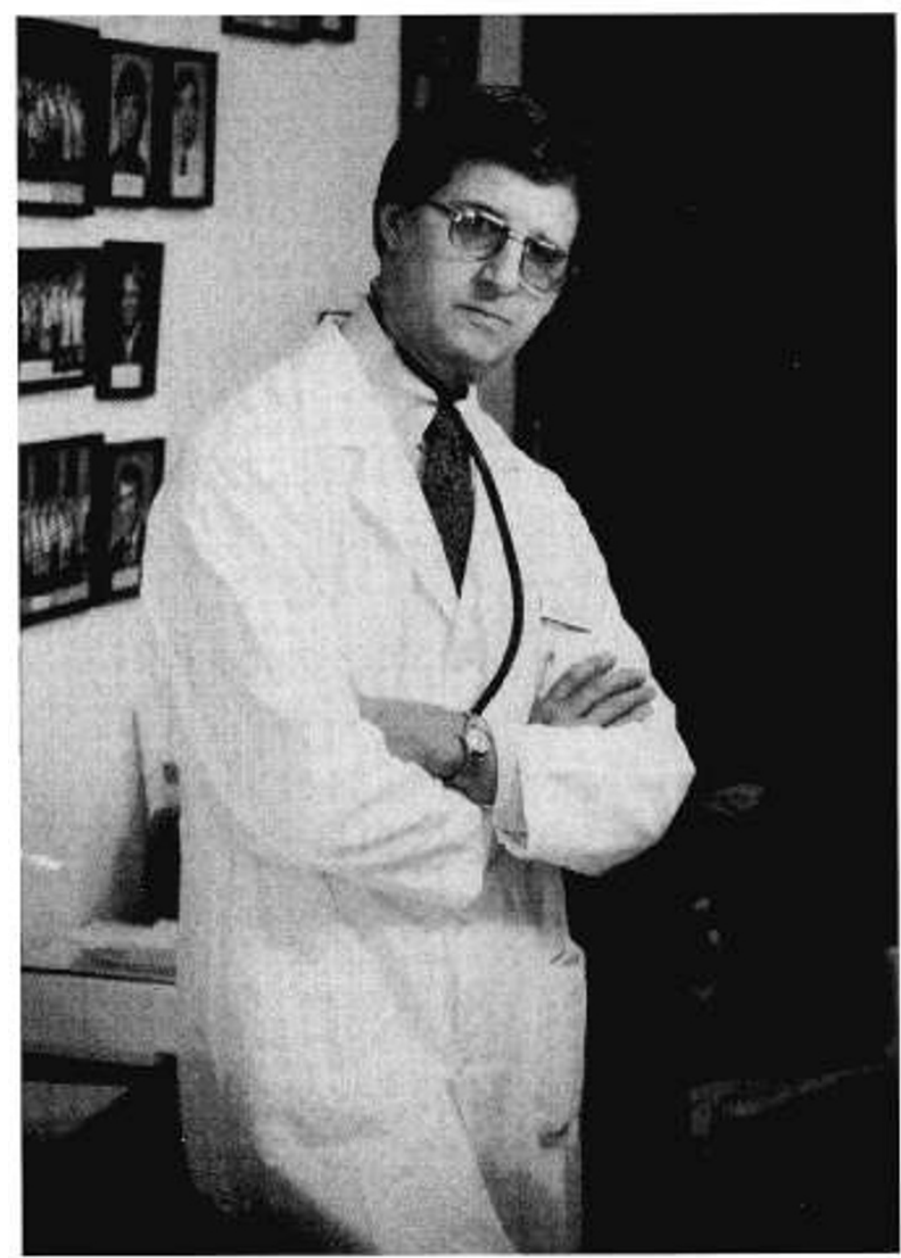

Figure 5. Portrait of Floyd W. Denny commissioned by his residents.

Carolina School of Medicine, has been a profound influence on our professional careers. More than any other individual he has molded our approach to the health care of children. We aspire to have ...(our practice) reflect the principles of scholarship, intellectual honesty and love of children that he taught us by precept and example. To this end in appreciation we dedicate this practice to him."

\section{CONCLUSION}

There are many who make outstanding contributions in one or two areas of academic medicine. Few are outstanding across a broad spectrum of academic activities. In this respect, Floyd Denny is exceptional! He has been a model clinician, a wise and revered teacher, an imaginative and productive investigator, a highly successful department chairman, an inspirational leader, and shaper of health policy for children everywhere. This amazing array of contributions has consistently been fueled by his uncompromising commitment to excellence. In sum, Floyd W. Denny exemplifies all of the finest attributes that the American Pediatric Society strives to foster. 